
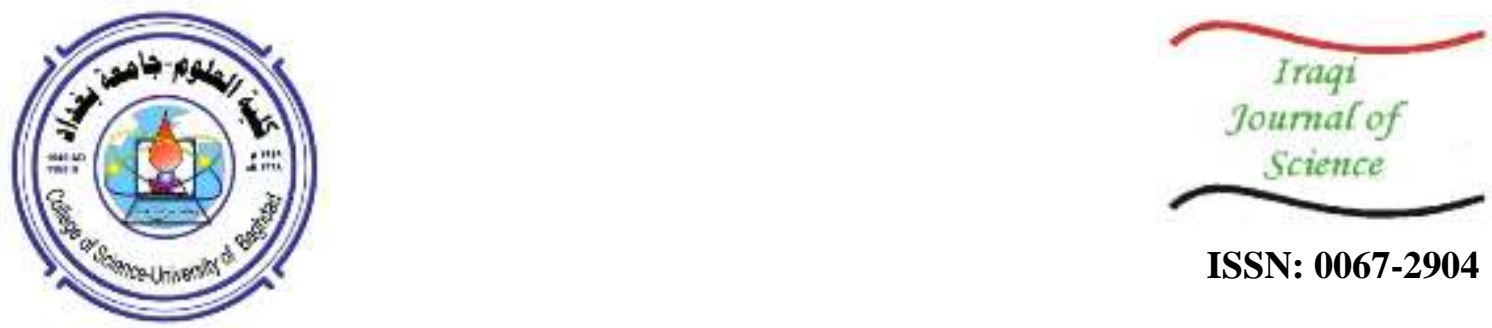

ISSN: 0067-2904

\title{
Evaluation the correlation between IL-17 level and autoimmune antibodies in hypo and hyper thyroidisms Iraqi patients
}

\author{
Marwah F.Fadhil, Shaima R.Ibraheem, Abdul Al-Kareem A. Al-Kazaz \\ Department of Biotechnology, College of Science, Baghdad University, Baghdad, Iraq
}

\begin{abstract}
The current study included measuring the level of IL-17A and IL-17F and some autoimmune antibodies related to the thyroid gland in case of hypo and hyperthyroid in Iraqi patients to evaluate the correlation between all the measured parameters in this study. The study has been carried out in AL-Kindey Endocrine Gland and Diabetic Center in Baghdad during the period between February 2018 and May 2018, included: 88 patients were divided into three groups, The first group composed of 30 patients of Hypothyroidism that included (26) of them were females, (4) of them males. The second group composed of 30 of patients of Hyperthyroidism that included (20) of them were females, (10) of them were males - and second groups were conducted with hypo and hyperthyroidism respectively. While the third group composed of 28 of healthy individuals (Control) that composed of (25) of them were females, (3) of them were males was represented as control .The results revealed a significant $(\mathrm{P}<0.05)$ correlation between TSH concentration and age in patients groups. When the age is more than 40 years, the concentration of TSH was noticed to be higher than that in patients aged less than 40 years. The results show that the level of antibodies was significantly increased $(\mathrm{P}<0.01)$ in hypo and hyperthyroid patients in comparison with the control group. At the same time the level of Anti-TG antibodies was higher significantly in the hypothyroid patients than its level in hyperthyroid patients group. No significant differences have been found between hypo and hyperthyroid patients in the level of Anti-TPO and Anti TSH-R antibodies. But its noticed that the higher level of Anti-TPO Ab. was found in the hypothyroid group where as higher level of Anti TSH-R Ab. was found in the hyperthyroid group and simultaneously both types were significantly higher than their levels in the control group As well as the results demonstrated a highly significant increase $(\mathrm{P}<0.01)$ in the levels of IL-17 Types (A and F) in hypo and hyperthyroid patients with bias toward the comparison with the control group. The statistical study showed a significant negative correlation between the level of TSH and Anti-TG levels $(r=-0.33)$. While a significant positive correlation between the level of Anti-TG and level of IL-17F ( $r=0.39)$ in hypothyroid patients. Also in hypothyroid patients, there is a significant positive correlation between the level of Anti-TPO and IL-17A ( $\mathrm{r}=0.33)$. In conclusion: The positive correlation between IL-17F and Anti-TG and between IL-17A and AntiTPO in hypothyroid patients refer to increase in the concentration of IL-17 may lead to increase the thyroid autoantibodies, which affect thyroid tissue potency, decreasing thyroid hormone production, according to feedback inhibition loop. Keywords: Hypothyroidism, Hyperthyroidism, Anti-TPO, Anti-TG,
\end{abstract}

\section{تقييم الارتباط بين مستوى الأنترلوكين -17 والأضداد الأتية لاى مرضى قصور وفرط الدرقية العراقين$$
\text { مروة فرحان فاضل، شيماء رناق ابراهيم، عبد الكريم عبد الرزلق القزاز }
$$$$
\text { قسم التقنيات الاحيائية ، كلية العلوم ، جامعة بغداد ، بغداد ، العراق ابعراق }
$$

*Email: marwabiotech94@gmail.com 


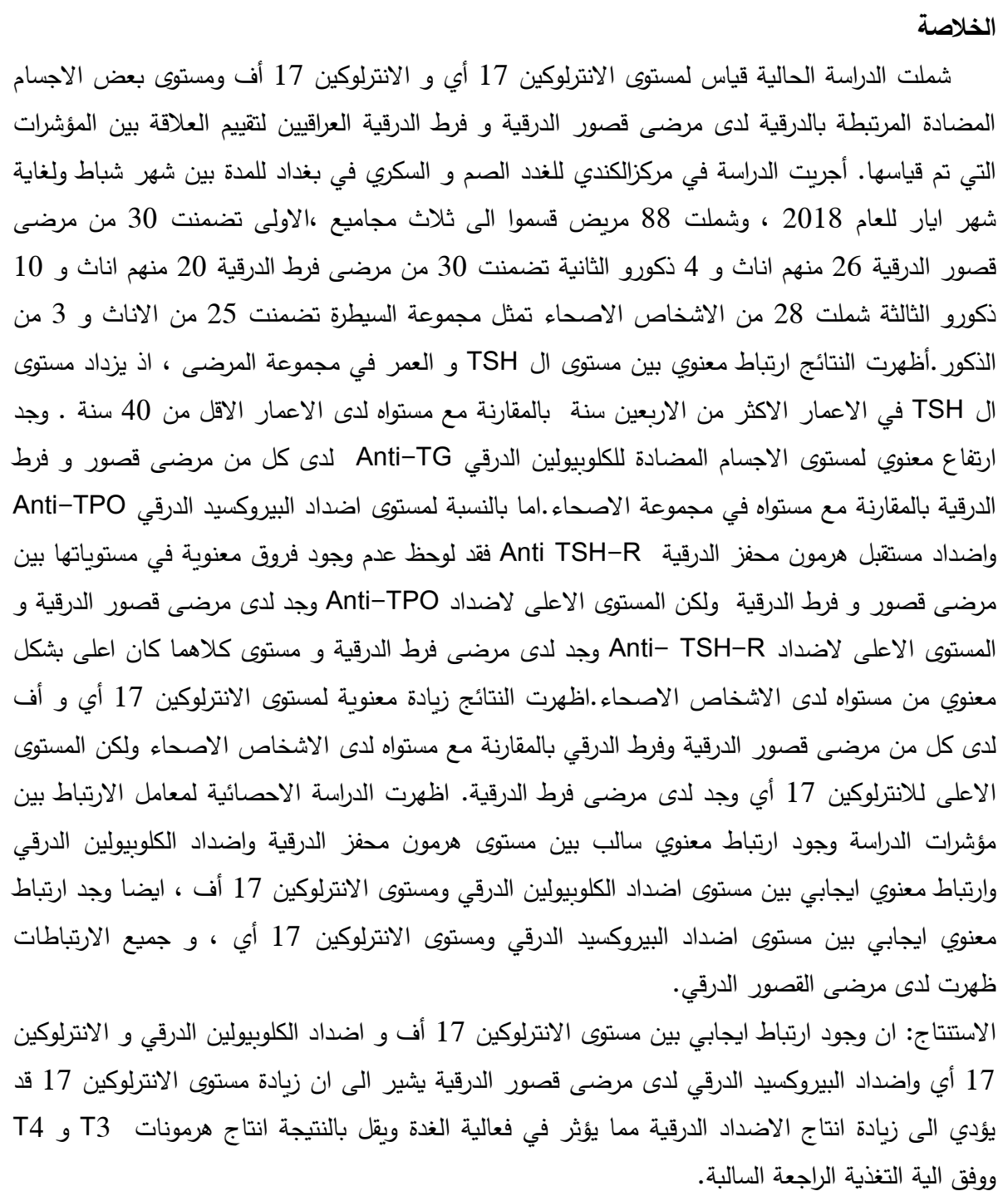

\section{Introduction}

Hypothyroidism is a common endocrine disorder resulting from deficiency of thyroid hormone or, more rarely, from their impaired activity at the tissue level. Deficiency of the hormone has a wide range of effects, because all metabolically active cells require thyroid hormone [1]. The common forms of autoimmune Thyroiditis are Hashimoto's thyroiditis (HT) is characterized by progressive loss of follicular cells and replacement of lymphoid infiltrates and fibrosis [2].

Hyperthyroidism is a pathological disorder characterized by excess thyroid hormone synthesis and secreted by the thyroid gland [3]. Graves' Disease, the common cause of hyperthyroidism is an autoimmune disease that thyroid stimulating antibodies activate TSH- Receptors and induce synthesis of thyroid hormones [4].

Autoimmune thyroid disease (AITD) is the most common specific autoimmune disorder which affects mostly the middle-aged women. About (2-4) \% of women and up to $1 \%$ of men are affected, and the prevalence rate increases with advancing age [5]. Autoimmune thyroid diseases (AITD) is considerable evidence implicating that the actual destruction of thyroid cells in AITD may be caused by different and multiple mechanisms, including autoreactive T-lymphocytes, natural killer (NK) cells, and cytokines [6].

The disease was diagnosed by the presence of serum autoantibodies, anti-thyroid peroxidase is considered the best serological marker for the diagnosis of HT , approximately $95 \%$ of patients with HT are positive for Anti-TPO , while Anti-Thyroglobulin is positive in nearly 60-70\% of HT patients and are found to be positive in higher percentage of healthy people [7]. 
IL-17 family that involved six members (IL-17A, IL-17B, IL-17C,IL-17D,IL-17E (or IL-25), and IL17F [8]. The main source of IL-17A and IL-17F is type T helper 17 cells (TH17 cells), which also produce cytokines such as IL-22 and IL-21. IL-17 play important role in the pathogenesis of autoimmune diseases.The levels of IL-17 are found elevated in patients with rheumatoid arthritis, systemic lupus erythematous (SLE) and in Psoriasis [9] .

The present study was aimed to evaluate the serum level of IL-17A and IL-17F in hypo and hyperthyroid patients and study its association with the thyroid- related autoimmune antibodies.

\section{Materials and Methods:}

The current study has been carried out in AL-Kindey for Endocrine Gland and Diabetic Center in Baghdad during the period between February 2018 and May 2018, include: 88 subjects were divided into three groups, The first group composed of 30 patients of Hypothyroidism that included (26) of them were females, and (4) of them males. The second group composed of 30 of patients of Hyperthyroidism that included (20) of them were females, and (10) of them were males. While the third group composed of 28 of healthy individuals (Control) that composed of (25) of them were females, and (3) of them were males. The current study includes patients of hyper and hypothyroidism their age range between $(20-64)$ year, and healthy individuals represented as the control group, their age range between $(23-58)$ years.

Venous blood samples $(3 \mathrm{ml})$ were taken from all subjects of the studied groups, centrifuged at 3000 rpm for 5 minutes. The collected serum kept in the freezer $\left(-20{ }^{\circ} \mathrm{C}\right)$ until use to determine The Biochemical, Immunological parameters according to the manufacturer's protocol.

As indicators of thyroid function, T3, T4, TSH level were estimated using Biomerieux (France) kits. Autoantibodies (TPO and TG) were estimated using immunolab (Germany) ELISA kits. Anti TSH-R Ab.were estimated using MyBiosource (USA) ELISA kits and cytokines (IL-17A and IL-17F) were estimated using Diaclone SAS (France) ELISA kits.

Body weight was measured using an analog scale, all calculations were made using a standard statistical package (SPSS for Windows software- V.24), used to test the difference between three groups on the study parameters. Data were expressed as (mean $\pm \mathrm{SE}$ ) with $\mathrm{P}<0.05$ considered to be significant and $\mathrm{P}<0.01$ considered to be highly significant.

\section{Results and Discussion}

The results revealed a significant $(\mathrm{P}<0.05$ ) association between TSH concentration and age in patients group as shown in (Figure-1) .This result agree with the study of (Hoogendoorn et al. , 2006), in which TSH concentration decreases when age is increased in hypothyroidism patients. The results in this study elucidated that,when age is less than 40 years the mean concentration of TSH is ( $34.29 \pm$ $8.20) \mu \mathrm{IU} / \mathrm{ml}$ while in age more than 40 years the mean concentration of TSH is $(22.10 \pm 3.55)$ $\mu \mathrm{IU} / \mathrm{ml}$.

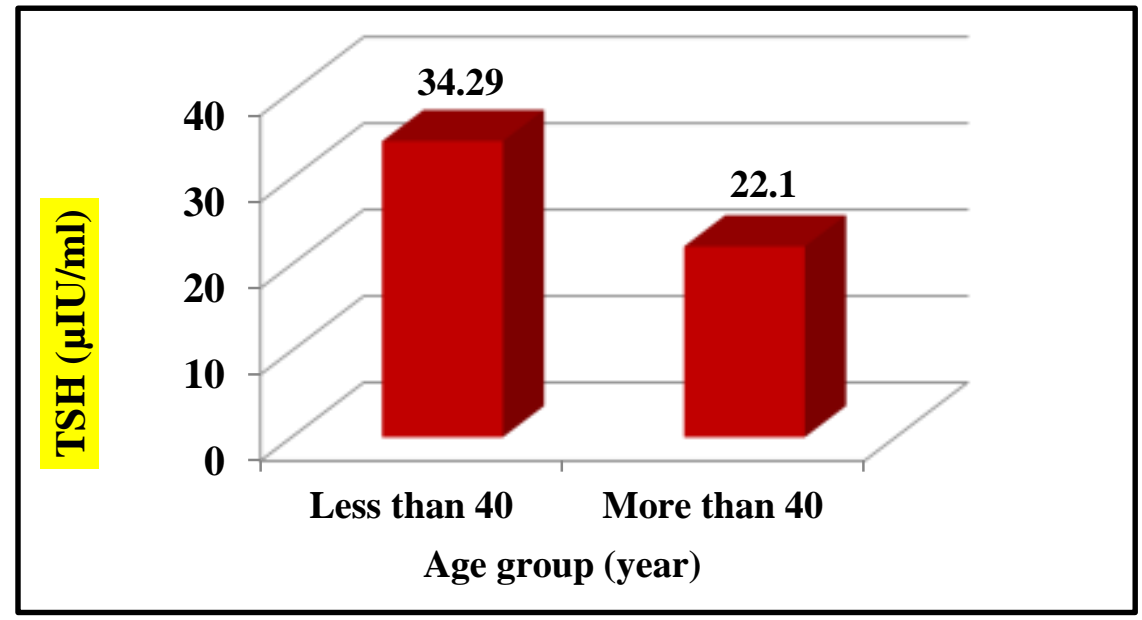

Figure 1 -Effect of age in level of TSH in hypothyroidism patients group.

This study shows that the average body weight of hypothyroid patients was higher than its average in hyperthyroid patients and control, (Figure-2). Body weight related to thyroid hormones ,since thyroid hormones regulate basal metabolism, thermogenesis and play a role in lipid and glucose 
metabolism, food intake and fat oxidation ,therefore any disturbance in thyroid gland function may cause changes in body weight and composition, body temperature and total and resting energy expenditure (REE) [10].

Thyroid hormones (T3 and T4) accelerate metabolic pathways, therefore, decreasing its level encourage the body to store excess energy in the adipose tissue, that why body weight increase in hypothyroid cases. Besides, it was found that even a slight increase in serum TSH levels are associated with an increase in the increase in obesity [11].

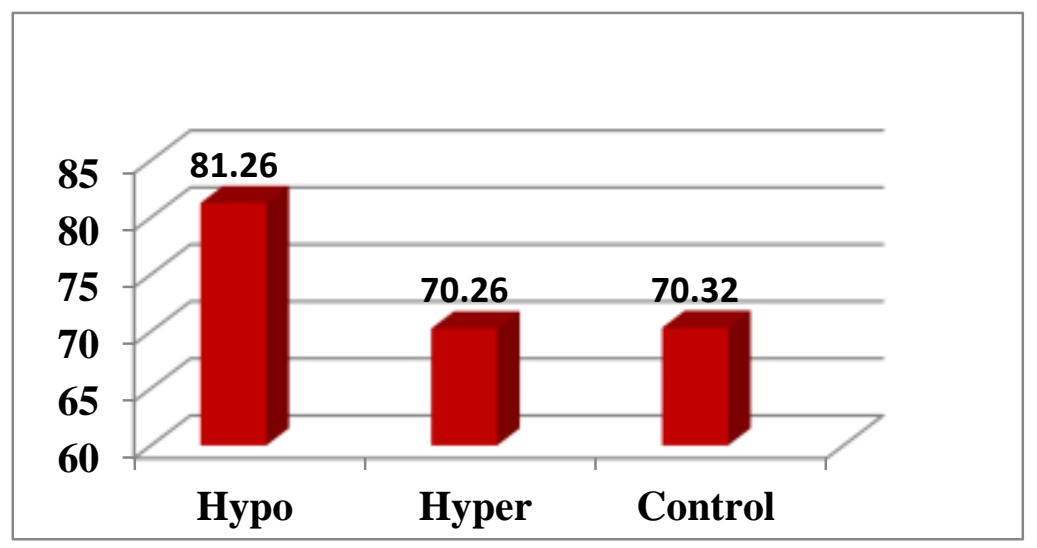

Figure 2-Weight percentage among study groups.

As shown in Table-1, the level of T3 hormone in hypothyroid patients was lower than its level in the other groups, statistically no significant differences have been found in the T3 level between hypothyroid patients and control group.T3 level in hyperthyroid patients was higher significantly than its level in hypothyroid group in comparison with the control group. Otherwise, the T4 hormone level differs significantly between the three groups, the lowest level is found in hypothyroid patients. Significant higher levels of TSH were found in hypothyroid patients compared with the control group .Whereas no significant differences in TSH level between hyperthyroid patients and control group. TSH level in hypothyroid patients higher was significantly than its level in the control group.

Table 1-Levels of thyroid functions tests ( T3, T4, TSH ) in the study groups .

\begin{tabular}{|c|c|c|c|}
\hline \multirow{2}{*}{ Groups } & \multicolumn{3}{|c|}{ Mean \pm SE } \\
\cline { 2 - 4 } & T3 $(\mathrm{nmol} / \mathrm{l})$ & T4 $(\mathrm{nmol} / \mathrm{l})$ & TSH $(\mathrm{nmol} / \mathrm{l})$ \\
\hline Hypothyroidism & $1.270 \pm 0.07 \mathrm{~b}$ & $\mathbf{6 1 . 1 8} \pm 4.71 \mathrm{c}$ & $\mathbf{2 5 . 7 5} \pm 3.57 \mathrm{a}$ \\
\hline Hyperthyroidism & $\mathbf{2 . 9 8 6 \pm 0 . 2 6 \mathrm { a }}$ & $\mathbf{1 2 2 . 5 0 \pm 8 . 1 1 \mathrm { a }}$ & $\mathbf{0 . 0 8 1} \pm \mathbf{0 . 0 2} \mathrm{b}$ \\
\hline Control & $1.721 \pm 0.05 \mathrm{~b}$ & $\mathbf{8 5 . 7 9} \pm 1.24 \mathrm{~b}$ & $\mathbf{2 . 0 8 2} \pm \mathbf{0 . 1 3} \mathrm{b}$ \\
\hline LSD value & $\mathbf{0 . 4 6 1} * *$ & $15.706 * *$ & $5.938 * *$ \\
\hline P-value & $\mathbf{0 . 0 0 0 1}$ & $\mathbf{0 . 0 0 0 1}$ & $\mathbf{0 . 0 0 0 1}$ \\
\hline
\end{tabular}

The failing in thyroid gland activity that leads to an increase or decrease in the secretion of these hormones may result in thyroid disorder [12]. Hypothyroidism was the commonest thyroid disorders observed, characterized by increased serum TSH levels with reduced T3 and T4 hormone production, while the hyperthyroidism was characterized with over-production of T3 and T4 hormones and decreased TSH levels [13]. The elevated of T3 and T4 due to negative feedback mechanisms [14]. About half hypothyroidism cases are due to autoimmune destruction [15]. Hashimoto's thyroiditis, an autoimmune disease often able to progressively destroy the thyroid gland, represents the most common cause of acquired subclinical or overt hypothyroidism in adults in areas of iodine sufficiency [16]. The frequently causes of hyperthyroidism are Graves' disease and toxic nodular goiter [17].

The results show that the level of Anti-TG antibodies was significantly increased $(\mathrm{P}>0.01)$ in hypothyroid patients group in comparison with the control group $(1909.29 \pm 239.71$ vs $142.91 \pm$ $56.02) \mathrm{IU} / \mathrm{ml}$, as well as in the hyperthyroid patients group $(1223.97 \pm 239.58$ vs $142.91 \pm 56.02)$ $\mathrm{IU} / \mathrm{ml}$. At the same time the level of Anti- TG antibodies was higher significantly in hypothyroid 
patients than its level in hyperthyroid patients group $(1909.29 \pm 239.71 \mathrm{vs} 1223.97 \pm 239.58) \mathrm{IU} / \mathrm{ml}$ as illustrated in (Figure-3).

No significant differences have been found between hypothyroid and hyperthyroid patients in the level of Anti-TPO and Anti TSH-R antibodies. But its noticed that the higher level of Anti-TPO Ab. was found in hypothyroid group $(1989.68 \pm 254.53 \mathrm{vs} 191.16 \pm 47.96) \mathrm{IU} / \mathrm{ml}$ and the higher level of Anti TSH-R Ab. was found in hyperthyroid group (11.23 \pm 0.56 vs $5.034 \pm 0.41) \mathrm{IU} / \mathrm{ml}$ and both types were higher significantly than their levels in the control group Figures- $(4,5)$

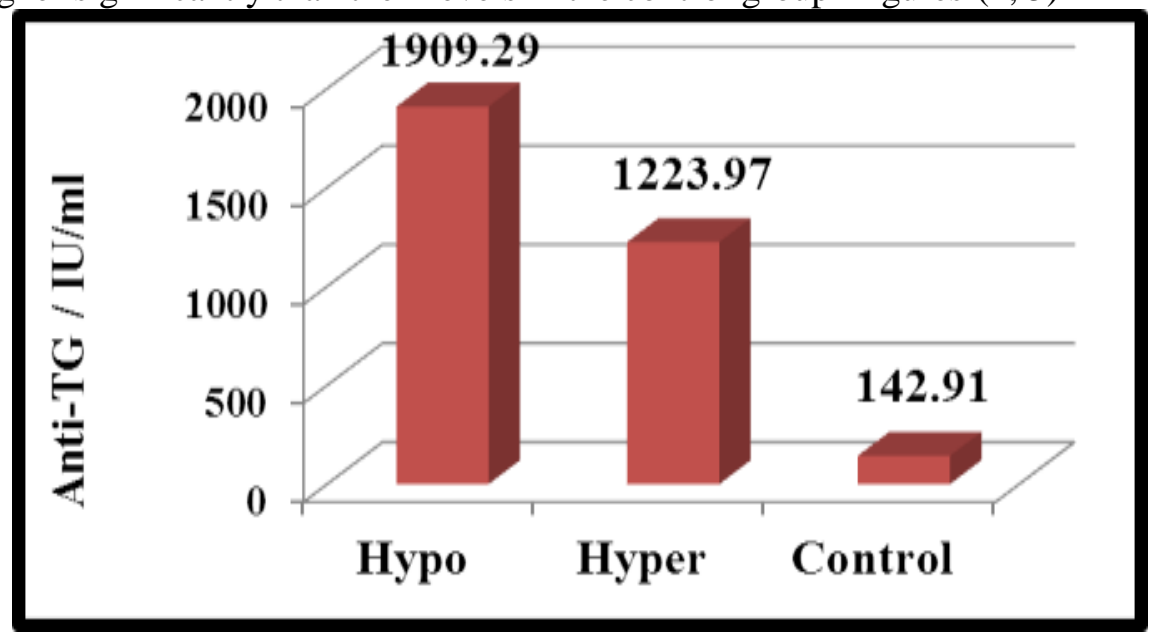

Figure 3-The levels of Anti-thyroglobulin antibodies in groups of this study

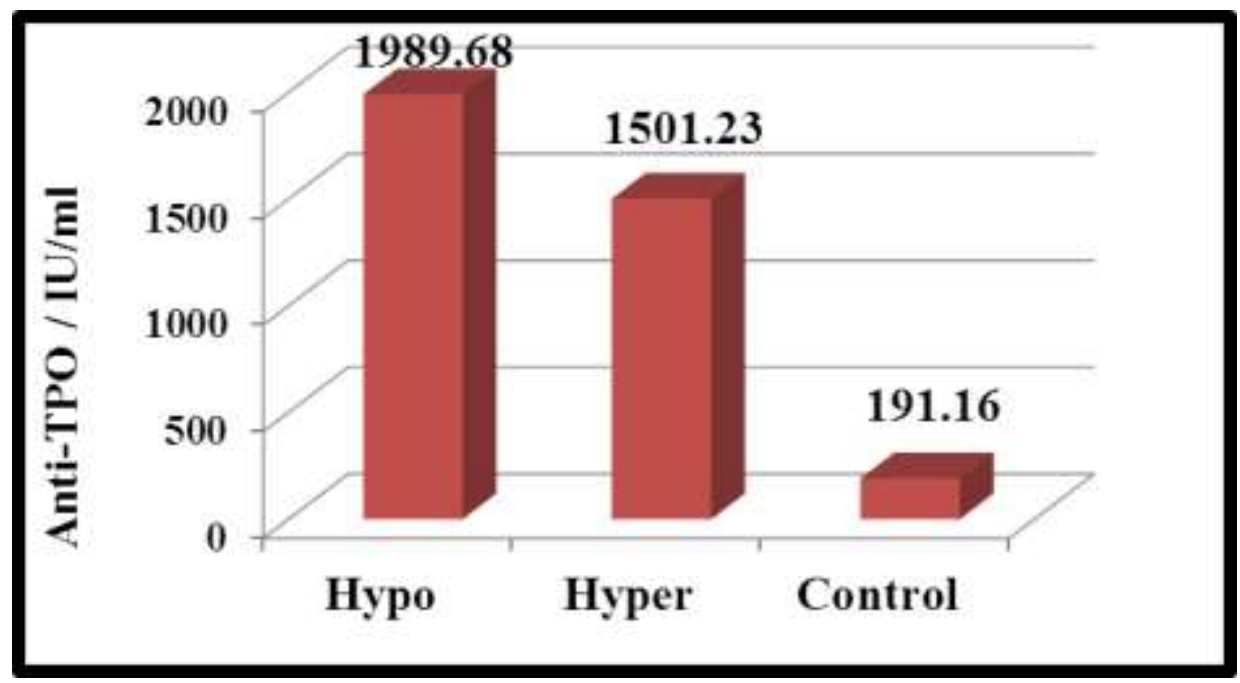

Figure 4-The level of Anti-Thyroid Peroxidase in groups of this study

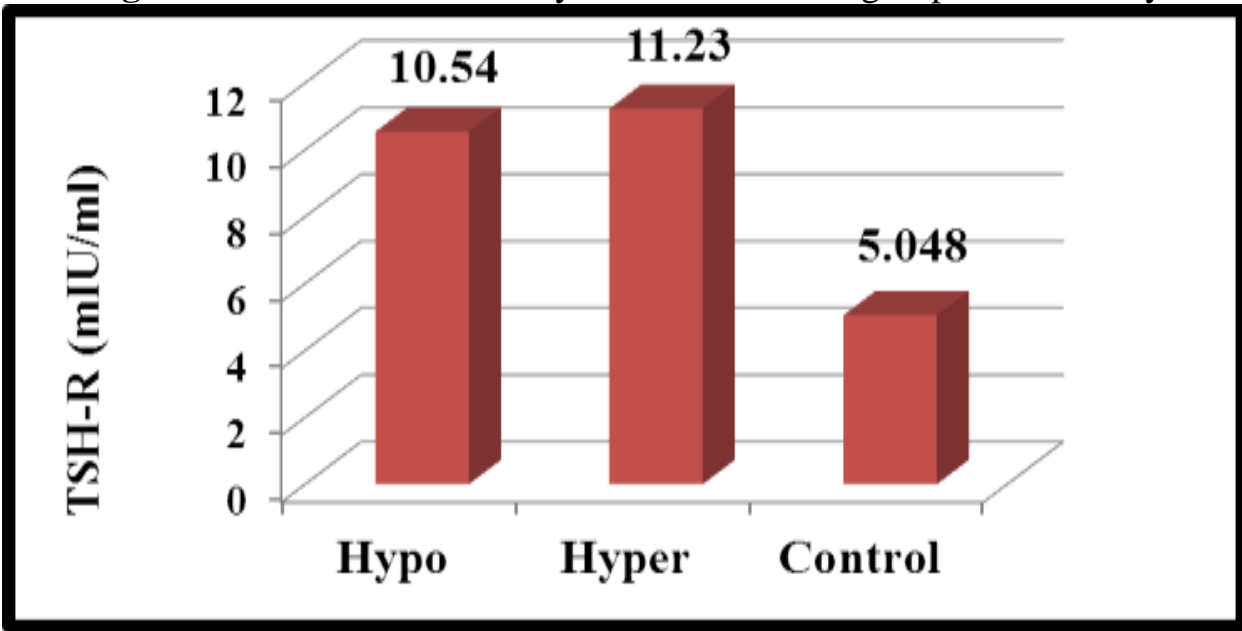

Figure 5-The level of TSH-Receptor antibodies in groups of this study 
The elevated of autoantibodies that increased probability of patients that have an autoimmune disease (Graves' disease and Hashimoto's Thyroiditis ) because patients produced high levels of thyroid autoantibody and contain lymphoid tissue that resembles secondary lymphoid follicles [18] (Armengol et al. , 2001).

The result of the present study disagree with the results of Elmugadam et al. , (2010) [19] study which revealed insignificant differences between hypothyroidism $14 \%$ and hyperthyroidism $7.5 \%$ and control group, However observed $27.8 \%$ and $66.7 \%$ were positive to Anti-TG in Graves' and Hashimoto's diseases patients respectively .

Chronic hypothyroidism is most closely associated with Hashimoto's thyroiditis, all types of thyroiditis may progress to permanent hypothyroidism .The outcome is more likely in patients with higher serum concentrations of thyroid antibodies or in patients whom a more severe hypothyroid phase develops. The hypothyroid phase of thyroiditis results from the gradual depletion of stored thyroid hormones [20].

Anti-TG it is an intra-follicular antibody that can bind to immune cells and antigens with or without tissue destruction. Massive destruction of thyroid gland induces a structural change in TG leading to antibody production against TG. Major T-cell epitopes on TG require iodination for recognition by autoreactive T-cell [21] .The study of Sultana et al. , (2016) [22] showed elevation of Anti-TG in hypothyroidism and hyperthyroidism patients about $41.81 \%$ and $40 \%$ was positive to Anti-TG respectively .

Dham et al. , (1995) [23] observed that Anti-TPO positive in 58.3\% of primary hypothyroidism and in $70 \%$ of primary thyrotoxicosis and in $100 \%$ of Hashimoto's disease and the study showed a significant elevation in IgG in Graves' disease.Another study by Sultana et al. , (2016) [22] revealed that seropositivity of Anti-TPO in patients with hypothyroidism is about (54.54\%), while in patients with hyperthyroidism is about ( $53.33 \%$ ) and approximately agreed with the current study, also its noticed that prevalence of Anti-TPO ,as well as Anti-TG together, comprise $69.09 \%$ in hypothyroidism and $66.66 \%$ in hyperthyroidism cases which indicate to high seropositivity when these autoantibodies are elevated together in patients. Swain et al. , (2005) [24] observed that AntiTPO is above $60 \%$ in hypothyroidism .

Thyroid autoantibodies are the markers of autoimmunity in autoimmune thyroid diseases [25] (AlNaqdy et al. , 2003). another study in Iraqi patients by AL-A'araji , (2016) [26] that revealed high occurrence of Anti-TPO in hypothyroidism and hyperthyroidism patients groups .Another study observed that $66.7 \%$ and $50 \%$ are positive to Anti-TPO in hypothyroidism and hyperthyroidism patients respectively [27].

Anti-TPO was considered to be a sensitive marker for autoimmune thyroid disease [28]. In the study performed in Norway reveal an association between Anti-TPO level and abnormally low and high TSH concentration [29]. Jayashankar et al. , 2015 [30] in their study found that about 80\% and 50\% of clinical and subclinical respectively positive to Anti-TPO. While the study of Mohanty et al. , 2008 [31] noted that $73.78 \%$ of subclinical hypothyroidism patient were positive to Anti-TPO. About $90 \%$ of Brazilian women patients with autoimmune thyroiditis have elevated levels of Anti-TPO [32].

TPO is an enzyme that responsible for iodination of tyrosine residues and coupling of iodinated residues to synthesis thyroid hormone [33]. Higher seropositivity in TPO that compared to TG because of a variable is differences in antigenic characteristic of these two thyroid antigens [22]. FigueroaVega et al., (2010) [34] found an elevation of TSH-R in Graves' patients but not in Hashimoto's patients.

The results demonstrated a highly significant increase $(\mathrm{P}<0.01)$ in the levels of IL-17A in hypo and hyperthyroid pateints in comparison with the control group $(9.24 \pm 1.17$ vs $3.40 \pm 0.34) \mathrm{Pg} / \mathrm{ml}$ and $(14.21 \pm 1.08$ vs $3.40 \pm 0.34) \mathrm{Pg} / \mathrm{ml}$ respectively. On the other hand Hyperthyroid patients have a higher level of IL-17A (Figure-6). Also, the study demonstrated a highly significant increase $(\mathrm{P}<0.01)$ in the levels of IL-17F in hypo and hyperthyroid patients in comparison with the control group (22.82 \pm 1.87 vs $3.60 \pm 0.31) \mathrm{Pg} / \mathrm{ml}$ and $(26.22 \pm 1.36$ vs $3.60 \pm 0.31) \mathrm{Pg} / \mathrm{ml}$ respectively. No Significant differences have been found in the levels of IL-17F between groups of patients in comparison with the control group $(22.82 \pm 1.87$ vs $3.60 \pm 0.31) \mathrm{Pg} / \mathrm{ml}$. (Figure-7).Also, Hyperthyroid patients have a higher level of IL-17F.( Figure-6) 


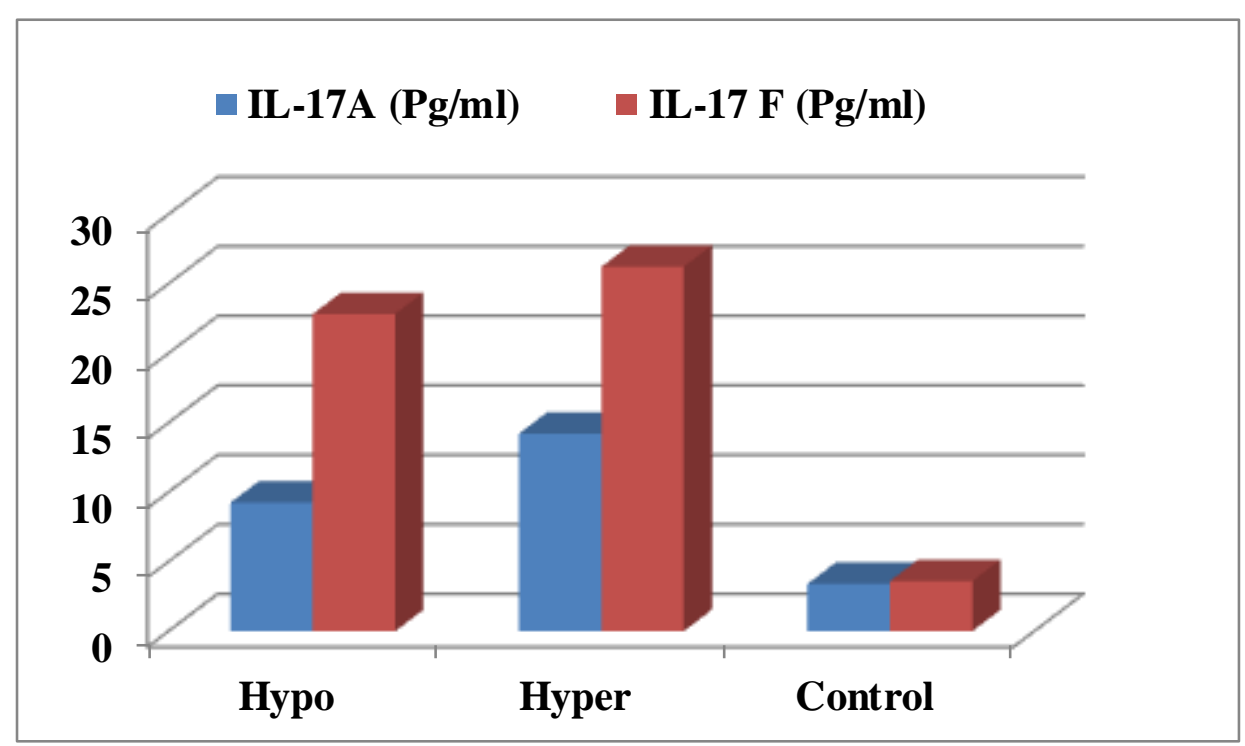

Figure 6-he levels of serum IL-17A and IL-17F in groups of patients and control group of this study.

The study of Cautha et al.,(2018) [35] showed increased levels of IL-17A in children with Hashimoto's disease, and suggested the possible role of IL-17A in the pathogenesis of this disease. Figueroa -vega et al. , (2010) [34] revealed an elevation in the levels of IL-17 and IL-22 ${ }^{+}$ lymphocytes and IL-17 mRNA levels in the blood and thyroid tissue of patients with Hashimoto's disease as compared to Graves' disease patients and control group. In China, Qin et al (2012) [36] found higher mRNA levels of IL-17A and INF- $\gamma$ in both peripheral blood mononuclear cells and thyroid tissue of Hashimoto's Thyroiditis patients than healthy control and higher also in Graves' disease patients but not significant concluded that similarly high levels of IL-17A suggested a mixed response of Th17 and Th1 in Hashimoto's Thyroiditis where both cells may play important roles in the destruction process by cell mediated cytotoxicity. However, our results agree with the Iranian study, in which the higher levels of serum IL-17A include all Hashimoto's disease patients and total hypothyroidism $(6.71 \pm 4.35)$, overt hypothyroidism patients $(7.51 \pm 4.85)$ and in subclinical hypothyroidism $(5.97 \pm 3.79)$ in comparisons with the control $(3.48 \pm 2.14)$ [37]. The levels of IL-17 were increased in Graves patients in comparison to control group [38].

The statistical study for the correlation between measured parameters, showed a significant negative correlation between the level of TSH and Anti-TG levels ( $r=-0.33)$, as shown in (Figure-7). A significant positive correlation in hypothyroid patients between the concentration of Anti-TG and concentration of IL-17F ( $\mathrm{r}=0.39$ ), as showed in (Figure-8). Also in hypothyroid patients, there is a significant positive correlation between level of Anti-TPO and IL-17A $(r=0.33)$, as illustrated in (Figure-9).

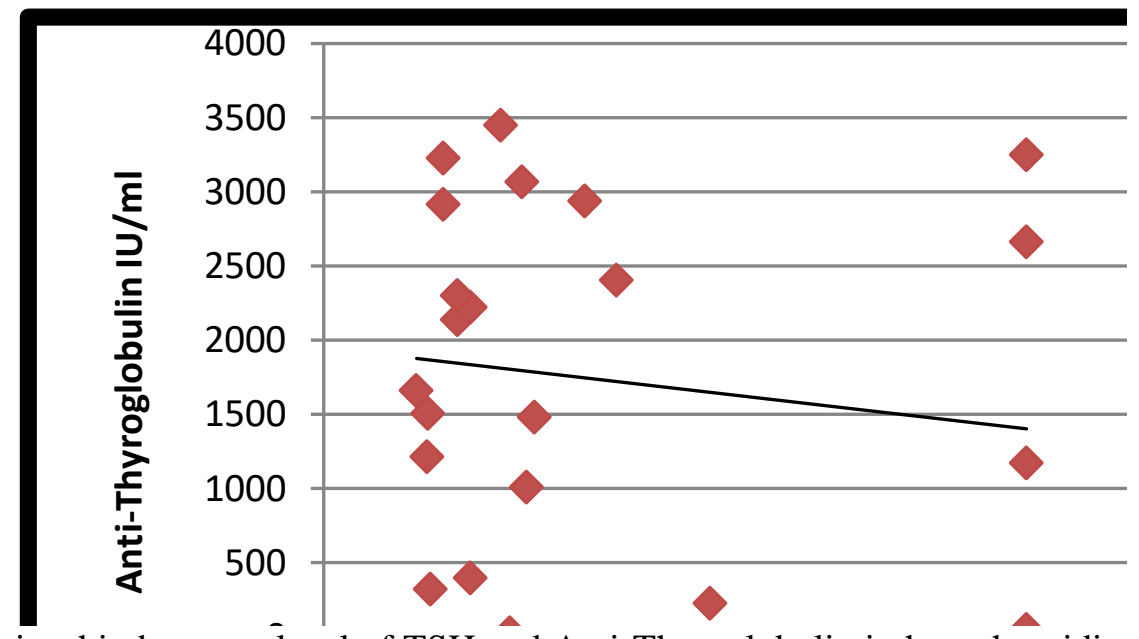

Figure 7-Relationship between level of TSH and Anti-Thyroglobulin in hypothyroidism patients (r= $0.33)$. 


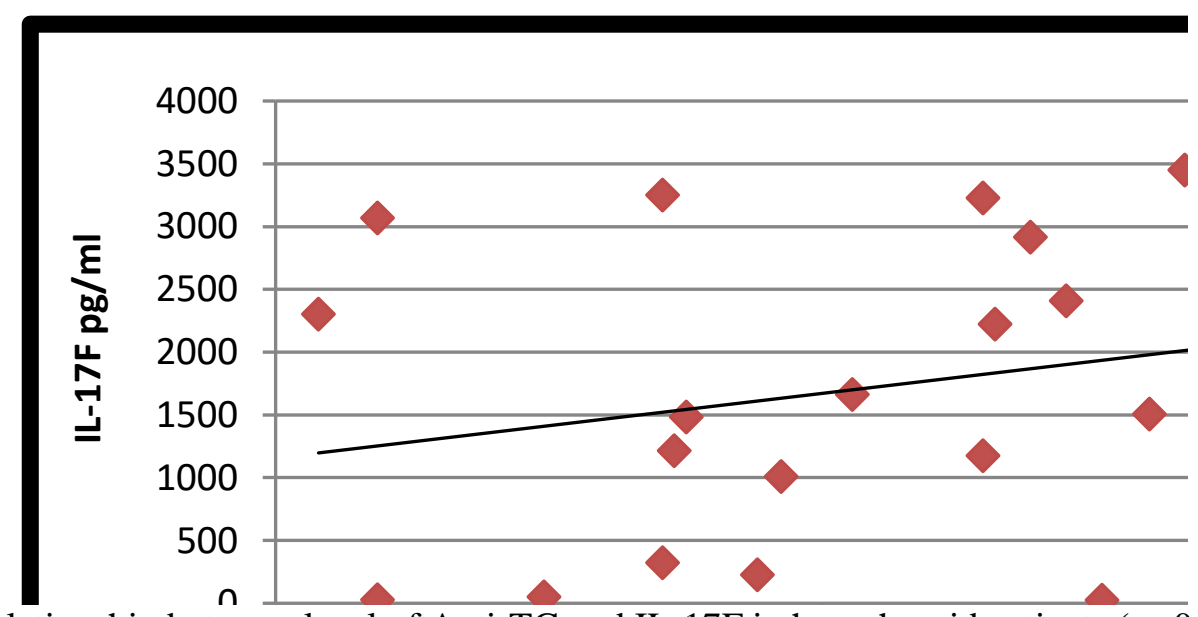

Figure 8-Relationship between level of Anti-TG and IL-17F in hypothyroid patients ( $\mathrm{r}=0.39)$.

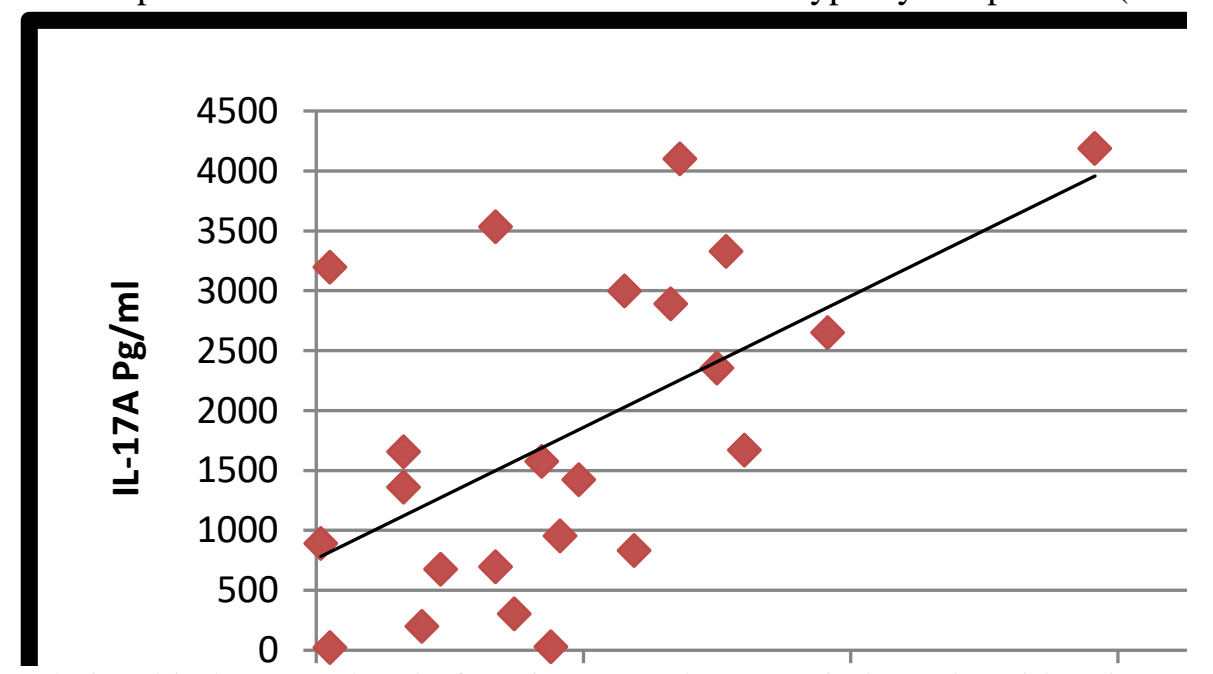

Figure 9-Relationship between level of Anti-TPO and IL-17A in hypothyroid patients. ( $\mathrm{r}=0.33)$.

Hashimoto's thyroiditis is the main cause of hypothyroidism, considered a Th-1 mediated disease [39]. The new subset of Th cell discovered called Th17 cell that implicated in different types of autoimmune diseases.Th17 cells mainly secrete of IL-17A and IL-17F which play an active role in the pathogenesis of HT [35. 37].

\section{References}

1. Bello, F and Bakarai, A.G. 2012. .Hypothyroidism in adults: A review and recent advances in management . J. Diabetes Endocrinol, 3(5): 57-69 .

2. Brown, R.S. 2013. Autoimmune thyroiditis in childhood. J Clin. Res. Pediatr. Endocrinol.; 5(Suppl 1): 45-49.

3. Bahn, R.S., Burch, H.B., Cooper, D.S., , Garber, J.R., Greenlee, M.C., Klein, I., Laurberg, P., McDougall, I.R., Montori, V.M., Rivkees, S.A., Ross, D.S., Sosa ,J.A. and Stan, M.N.. 2011. Hyperthyroidism and other causes of thyrotoxicosis: management guidelines of the American Thyroid Association and American Association of Clinical Endocrinologists. Endocr Pract.; 17(3): 456-520.

4. Morshed, S.A., Latif, R. and Davies., T.F. 2015. Delineating the autoimmune mechanisms in Graves' disease.Immunol Res. 54(0): 191-203.

5. Canaris, G.J., Manowitz, N.R., Mayor, G.M. and Ridgway, E.C. 2000 The Colorado thyroid disease prevalence studies. Arch. Int. Med. 160: 526-534.

6. Klecha, A. J., Barreiro Arcos, M.L., Frick, L., Genaro, A.M. and Cremaschi, G. 2008. Immuneendocrine interactions in autoimmune thyroid diseases. Neuroimmunomodulation, 15(1): 68-75. 
7. McLachlan, S.M. and Rapoport, B. 2004. Why measure thyroglobulin auto-antibodies rather thyroid peroxidase autoantibodies? Thyroid; 14(7): 510-520.

8. Gaffen, S. L. 2009. Structure and signalling in the IL-17 receptor family. Nat. Rev. Immunol.; 9(8): 556-567.

9. Peng, D., Xu, B., Wang, Y., Guo, H. and Jiang, Y. 2013. A high frequency of circulating Th22 and Th17 cells in patients with new onset Graves' disease. PloS ONE; 8(7): 1-8.

10. Rosenbaum, M., Hirsch, J., Murphy, E. and Leibel, RL. 2000. Effects of changes in body weight on carbohydrate metabolism, catecholamine excretion, and thyroid function. Am. J. Clin. Nutr.; 71: $1421-32$.

11. Marras, V., Casini, M.R., Pilia, S., Carta, D., Civolani, P., Porcu, M., , Uccheddu, A.P. and Loche, S. 2010. Thyroid function in obese children and adolescents. Horm ResPaediatr. 73(3): 193-197.

12. Garg, A. and Vanderpump, K. 2013. Subclinical thyroid disease, Br. Med. Bull . 107(8): 101116.

13. Unnikrishnan, A.G., Karla, S., Sahay, R.K., Bantwal, G., Jhon, M. and Tewari, N. 2013. Prevalence of hypothyroidism in adults: An epidemiological study in eight cities of India. Ind. $J$. Endocr. Metab.; 17: 647-652.

14. Guyton, W.C. and Hall,.E. 1996.A Textbook of Medical Physiology. Philadelphia: W B Saunders \& Co;. p. 945-55.

15. Tomer, Y. and Huber, A. 2009: The etiology of autoimmune thyroid disease: a story of genes and environment. J. Autoimmune ., 32: 231-239

16. Cooper, D.S. and Biondi B. 2012.Subclinical thyroid disease. Lancet.; 379: 1142-54

17. Smith, T.J. and Hegedus, L. 2016. Graves' disease. N. Engl. J. Med.; 375: 1552-1565.

18. Armengol, M.P., Juan, M., Lucas-Martin, A., Femandez, M.T., Jaraquemada, D., Gallart, T. and Pujol-Borrell, R. 2001. Thyroid autoimmune disease: demonstration of thyroid antigen specific B cells and recombination activating gene expression in chemokine-containing active intrathyroidal germinal centers. Am J Pathol. 159(3): 861-873.

19. Elmugadam, A. A., Elobied, E. A., Elebaid, M. H., Makeen, A. M. 2010. Prevalence of Antithyroid peroxidase, and Anti-thyroglobulin in Sudanese patients with thyroid diseases .Egypt. Acad. J. biology. 2(2): 93-97.

20. Pearce,E.N. Farwell,A.P. and Braverman, L.E. 2003. Thyroiditis, N. Engl. J. Med. 348:2646-2655.

21. Barin, J.G., Talor, M.V., Sharma, R.B., Rose, N.R., Burek, C.L. 2005. Iodination of murine thyroglobulin enhances autoimmune reactivity in the NOD.H2 mouse. Clin. Exp. Immunol.; 142: 251-259

22. Sultana, Q., Anjum, A., Fathima, N., Siraj, M. and Ishaq, M. 2016. Seropositivity to anti-thyroid peroxidase and anti-thyroglobulin autoantibodies in hypo and hyper-thyroidism: Diagnostic and epidemiological significance. Indian J. Microbiol. Res.; 3(4): 368-372.

23. Dham, S.K., A.C, Dhananjayan, G. and Shetty, K.J. 1995 .Microsomal and thyroglobulin antibodies in thyroid disorders. MJAFI. 51: 247-250.

24. Swain, M., Swain, T. and, Mohanty, B.K. 2005 .Autoimmune thyroid disorders-an update. Indian J. Clin. Biochem.; 20(1): 9-17.

25. AL-Naqdy, A., Kutty, I., AL-Harthi, S., AL-Buloshi M. and AL-Maskari, M. 2003. AntiThyroglobulin and Anti-Thyroid Microsomal Antibodies in Thyroid Disorders. Bahrain Med. Bull. 25(3).

26. Al-A 'araji, S. B., Rasen T. F. And Kadhum R. A. 2016. Biochemical Study on Anti Thyroid Peroxidase in Type 2 Diabetic patients with thyroid disorders, Baghdad Science Journal; 13(4): 753-761.

27. Lucas, A., Julián, M.T., Cantón, A., Castell, C., Casamitjana, R., Martínez-Cáceres, E.M.and Granada, M.L. 2010. Undiagnosed thyroid dysfunction, thyroid antibodies, and iodine excretion in a Mediterranean population. Endocrine. ; 38(3): 391-396.

28. Demers, L.M. and Spencer, CA. 2003. Laboratory medicine practice guidelines: laboratory support for the diagnosis and monitoring of thyroid disease. Clin. Endocrinol.; 58: 138-140.

29. Bjoro, T., Holmen, J., Krüger, O., Midthjell, K., Hunstad, K., Schreiner, T. , Sandnes, L. and Brochmann, H. 2000. Prevalence of thyroid disease, thyroid dysfunction and thyroid peroxidase antibodies in a large, unselected population. The Health Study of Nord-Trondelag (HUNT). Eur. J. Edocrinol.; 143(5): 639-647. 
30. Jayashankar, C. A. , Avinash, S. , Shashidharan, B., Sarathi., Shruthi ,K. R. , Nikethan, D. and Harshavardhan, J. 2015. The prevalence of anti-thyroid peroxidase antibodies in subclinical and clinical hypothyroid patients . Int. J. Res. Med. Sci. 3(12): 3564-3566.

31. Mohanty, S., Amruthlal, W., Reddy, G.C., Kusumanjali, G., Kanagasabapathy, A.S. and Rao, P. 2008. Diagnostic strategies for subclinical hypothyroidism. Indian J. Clin. Biochem.; 23(3): 279282.

32. Silva, L.M., Chavez, J., Canalli, M.H. and Zanetti, C.R. 2003. Determination of IgG subclasses and avidity of antithyroid peroxidase antibodies in patients with subclinical hypothyroidism- a comparison with patients with overt hypothyroidism. Horm. Res.; 59(3): 118-124.

33. Twig, G,, Shina, A,, Amital ,H. and Shoenfeld, Y. 2012. Pathogenesis of infertility and recurrent pregnancy loss in thyroid autoimmunity. J Auto.; 38: 275-281.

34. Figueroa-Vega, N.,Alfonso-Pérez, M., Benedicto, I., Sánchez-Madrid, F.,González-Amaro, R. and Marazuela,M.2010.Increased circulating pro-inflammatory cytokines and Th17 lymphocytes in Hashimoto's thyroiditis. J. Clin. Endocrinol. Metab. 95(2): 953-962.

35. Cautha,S. , Dayal,D. , Sachdeva, N., Badal,D. , Attri, S.V. and Sodhi,K.S.2018.Serum concentrations of interleukin-17A but not interleukin-17F are elevated in children with recentonset Hashimoto's thyroiditis, Thyroid Res. Pract. 15(3): 128-131.

36. Qin, Q., Liu, P., Liu, L., Wang, R., Yan, N., Yang, J., Wang, X., Pandey, M. and Zhang, J.A. 2012 .The increased but non-predominant expression of Th17- and Th1-specific cytokines in Hashimoto's thyroiditis but not in Graves' disease. Braz. J. Med. Biol. Res. 45(12): 1202-1208.

37. Esfahanian, F,, Ghelich, R, Rashidian, H, and Jadali, Z. 2017.Increased levels of serum interleukin-17 in patients with Hashimoto's thyroiditis. Indian J. Endocrinol. Metab.; 21: 551554

38. Elvira, E. Nasrul, Y., Sofyan,Y., Decroli, E. and Darwin,E. 2018.Increased serum levels of interleukin-17 and transforming growth factor- $\beta$ in patients with Graves' disease, IOP Conf. Series: Earth and Environmental Science, 125/012163: 1-4

39. Nanba, T., Watanabe, M., Inoue, N. and Iwatani, Y. 2009. Increases of the Th1/Th2 cell ratio in severe Hashimoto's disease and in the proportion of Th17 cells in intractable Graves' disease. Thyroid ,19: 495-501. 